\title{
Cooperation of China and Russia in the Framework of the Asian Super Grid: Political and Legal Aspects
}

\author{
Submitted $10 / 12 / 18,1^{\text {st }}$ revision $10 / 1 / 19,2^{\text {nd }}$ revision $18 / 2 / 19,3^{\text {rd }}$ revision $28 / 2 / 19$, \\ accepted 3/3/19
}

\author{
Belikova K.M. ${ }^{1}$, Badaeva N.V. ${ }^{2}$, Akhmadova M.A. ${ }^{3}$ \\ Abstract:
}

The authors present data on the current situation regarding the organization of electricity exports and analyze the potential of the Russian Far East in electricity production in the context of the financial and investment interaction between China and Russia.

The research showed that by building up its own export potential in the electricity power industry will allow Russia to strengthen the existing electric power complex of the Russian regions bordering with China making qualitative changes in the structure of the trade balance between these countries with respect to energy resources.

The conclusion is that both countries will get benefits from such a development.

Keywords: Asian Super Grid, Russia, China, Japan, South Korea, electricity, Far East, Northeast Asia.

JEL Classification Codes: Q41, Q42, Q43, Q48, Q21, Q31, K29.

\section{Acknowledgment:}

This research was funded by the RFBR according to the research project № 18-011-00745 A "Common features and national peculiarities of civil regulation of investment activities in Russia, the People's Republic of China, Japan and South Korea on implementing integration projects of "a power grid", free trade zone and developing the Far East" (Grant recepient D.Sc., Prof. Ksenia M. Belikova, Peoples' Friendship University of Russia (RUDN University), www.rudn.ru)

\footnotetext{
${ }^{1}$ Doctor of Science (Law), Professor, Professor of the Department of "Civil Law and Proceedings and International Private law”, Peoples' Friendship University of Russia (RUDN University),Moscow, BelikovaKsenia@yandex.ru

${ }^{2}$ Candidate of Science (Law), Associate Professor of the Department of "Civil Law and Proceedings and International Private law”, Peoples' Friendship University of Russia (RUDN University), Moscow, natalya_b7@mail.ru ${ }^{3}$ Post-graduate of Department of Civil Law and Proceedings and International Private Law, Peoples' Friendship University of Russia (RUDN University), 4ernijkvadrat95@gmail.com
} 


\section{Introduction}

Currently, Russia has the objective to develop the Russian Far East. This territory, constituting $36 \%$ of the entire territory of Russia, is rich in resources, contains $30 \%$ of Russian reserves of coal, $20 \%$ of hydrocarbons, $25 \%$ of wood, and there are significant reserves of rare-earth and non-ferrous metals, but less than 5\% of Russia's population lives here. Therefore, although there is an enormous natural resource potential, the role of this region in the special literature is characterized as insignificant, since the unique opportunities remain practically untapped. The Russian border area in its turn still performs barrier in the economic sense rather than contact functions (Rensselaer, 2013).

The following can be singled out as the main reasons constraining the development of the Far East in the present conditions: 1) depopulation, i.e., a decrease in the population of the region, both due to natural loss and as a result of migration outflows; 2) insufficient development of transport, energy and information infrastructure; 3) slow innovation development (Kapustin, 2012).

Thus, the task of developing this Russian region is many-sided. It is one of the most important strategic tasks of the state and its solution is possible only by attracting investments to this region, including foreign ones. The main direction of the development of the Far East needs these investments - the implementation of large infrastructure projects. The solution of this task will attract labor reserves to the region, including foreign (Asian) and lead to the development of its infrastructure.

When analyzing directions and specific projects for the development of cooperation between Russia and the countries of Northeast Asia, first, the power industry deserves attention, since from one third to half of the total energy consumption in the world is generated in the form of electrical energy. Therefore, one of the largescale projects that form the basis for the integration of countries can be considered the work of integrating the energy systems of the countries into the "Asian energy super grid" ("super grid") (Farmer and Trancik, 2012).

The concept of creating the "Asian Super Grid" has existed for more than one decade. In 1998-2000 it was actively promoted by the Russian United Energy System of Russia JSC, which in 2003 signed a protocol on cooperation in this area with the Japanese corporation Sumitomo, but developments were subsequently suspended.

Currently, the idea of uniting the power systems of the countries of Northeast Asia is actively lobbied by representatives of the largest energy companies in these countries. For example, on March 30, 2016 in Beijing, a Memorandum between the State Grid Corporation of China, Japanese corporation Softbank, Gulf Corporation, the South Korean energy company Korea Electric Power Corporation and the Russian company Rosseti PJSC was signed in the framework of the final conference 
on global energy interaction (the Global Energy Interconnection Conference). In accordance with the provisions of this Memorandum, the parties agreed to jointly analyze national legislation, study the profitability of the integration project, and also detail the first phase of its implementation through peer consultations to develop an intergovernmental agreement (Movellan, 2016).

At the same time, it should be understood that the participation of countries in such an energy association is not possible without full trust between the partners and a favorable political environment, since such projects go beyond the standard agreements on energy export and import between countries. It seems that in this direction potential countries participating in the project have certain difficulties. For example, China's relations with South Korea are experiencing a decline after American missile defense systems are deployed on its territory. However, these obstacles are not fatal and the countries can overcome them in the foreseeable future.

In September 2016, President of Russia V.V. Putin openly expressed his support for the concept of creating an energy super grid for the first time at the Eastern Economic Forum in Vladivostok. Putin noted Russia's readiness to provide a longterm competitive price for electricity in the Asia-Pacific region for the project partner countries for the long-term period. To implement this project as soon as possible, he proposed to form an intergovernmental working group (Putin, 2016). Given the specificity of the power industry, which is the inability to accumulate the products it receives (i.e., electricity), there is a need for its permanent consumption.

Therefore, the question of the possibility of redistributing this energy to other regions and between countries is of relevance. There are such cases in practice (these are the interstate electric power associations GARABI (South America), ENTSO-E (Europe), the Energy Association of the MEKONG subregion (Asia) and others. Their functioning allowed the participating countries to resolve issues, including the development of mutually beneficial trade electricity, ensuring uninterrupted power supply to these regions, technological improvement of the energy infrastructure, etc.

In this regard, the findings of the joint study of Skoltech and the Institute of Energy Systems of the Siberian Branch of the Russian Academy of Sciences (SB RAS) deserve attention. They showed that the creation of links between the power systems of the countries of Northeast Asia has great potential regardless of which integration scenario is chosen. The volume of power flows between the participating countries of the project can reach $400 \mathrm{TWh}$ per year. In this case, the greatest efficiency is created not by bilateral, but by multilateral energy ties between Russia, China, Japan, Mongolia and the countries of the Korean Peninsula and, first, due to systemic effects. According to Skoltech estimates, these system effects are estimated at more than US\$ 24 billion per year, making it possible to reduce investment by US $\$ 65.5$ billion and reduce the need for generating capacity by $67 \mathrm{GWh}$. Japan and China get the largest share (about 60\%) of the system effects from the creation of the Asian energy grid due to no need to introduce new generating capacity, the use of 
cleaner and cheaper energy sources. Saving Japan is making alone by creating energy connections with the countries of Northeast Asia accounts to more than US\$ 14 billion in fuel costs per year. About $30-40 \%$ of this effect will be received by Russia. The exclusion of Russia from this process follows from the data of Skoltech, reduces the economic effect by US\$ 7.2 billion per year, saving investments by US\$ 26.7 billion and saving the need for generating capacity by $27.5 \mathrm{GWh}$. The very fact of the existence of the UNEG makes it possible to effectively use the system for the Europe-Russia-Asia energy bridge. The project will be useful for the environment. Although fossil fuels will continue to dominate the energy balance of the member countries, $77 \%$ of them will fall. By 2035 , this share will have fallen to $72 \%$ due to an increase in the share of renewable sources in the generation structure (Semashko, 2016).

The study presented in this article will start with understanding and analysis of approaches to the legal regulation of investment activities and legal provisions in the field of investment and their harmonization between Russia, China, Japan and South Korea with a review of the current state of cooperation with China and ways to deepen it, including through financial and investment interaction and cooperation. In the next article we will look at cooperation with Japan and South Korea. The choice of China is conditioned by its leading role among these countries in the production and consumption of electricity, as will be shown below.

\section{Methodology and indicators of China, Japan, Korea and Russia in the field of electric power}

The general state of the interstate electric power association of the countries of Northeast Asia - China, Japan and Korea, as well as Russia is considered in this paper from the standpoint of production and consumption of electricity using the method of comparative analysis. The system analysis method and the structural and functional method are applicable when examining major basic trends of the national energy strategy of the People's Republic of China (PRC) to identify the factors causing the need to deepen bilateral energy cooperation between the Russian Federation and China. It should be noted that the listed countries are significantly ahead of other regions of the world in terms of financial, industrial, energy and information resources, raw materials. Consequently, the share of these countries in the production and consumption of electricity is dynamically increasing (Figures 2 and 3).

Figure 2. The share of countries in the production of electricity in $2000^{4}$

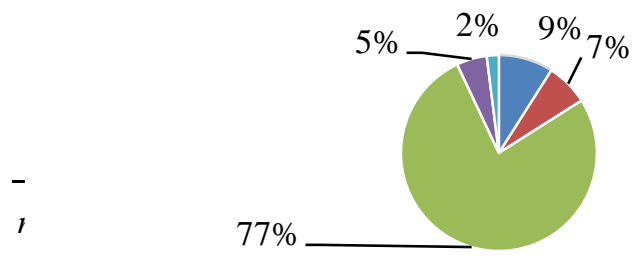

$$
\begin{aligned}
& \square \text { China } \\
& \square \text { Japan } \\
& - \text { Rest of the world } \\
& \square \text { Russia } \\
& \square \text { South Korea }
\end{aligned}
$$


Figure 3. The share of countries in the production of electricity in $2016^{5}$

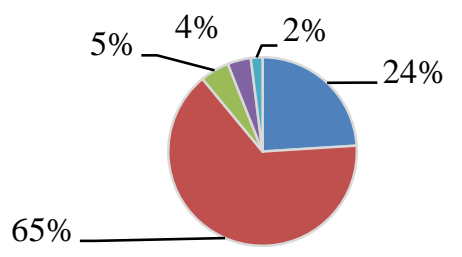

$$
\begin{aligned}
& \text { - China } \\
& \text { - Rest of the world } \\
& \text { - Russia } \\
& \text { - Japan } \\
& \text { 匹 South Korea }
\end{aligned}
$$

Thus, the indicators illustrated in these graphs allow establishing that, against the background of the rapid growth of the Chinese economy over the past 16 years, the production of electric power in this country has been 3 times higher. Consequently, electricity consumption by the population and industry has increased on a similar scale (Figures 4 and 5).

Figure 4. The share of countries in the consumption of electricity in $2000^{6}$

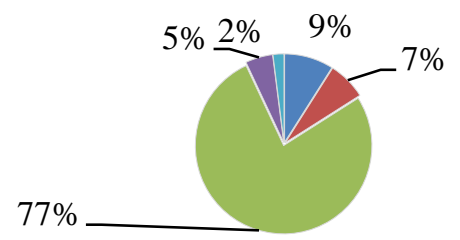

$$
\begin{aligned}
& \text { China } \\
& \square \text { Japan } \\
& \text { Rest of the world } \\
& \square \text { Russia } \\
& \square \text { South Korea }
\end{aligned}
$$

Figure 5. The share of countries in the consumption of electricity in $2016^{7}$

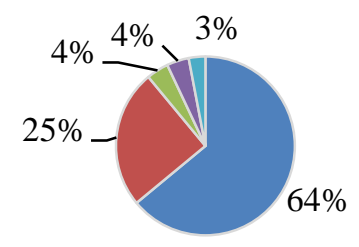

$$
\begin{aligned}
& \text { - Rest of the world } \\
& \text { a China } \\
& \text { - Japan } \\
& \text { - Russia } \\
& \text { I South Korea }
\end{aligned}
$$

This data shows a significant increase in power consumption in China, which is the locomotive of the economic life of the region. It was possible to achieve a similar balance in the provision of electricity by the adoption of the Program for the Development of the Electric Power Industry and Power Engineering in 2004. According to the program, the state allocated US\$ 120 billion to build new power plants with modern, powerful power units, which made it possible to eliminate problems in the electricity supply and overcome the backlog of the country's electricity sector (Austin, 2005). At the same time, the electric power industry

\footnotetext{
${ }^{5}$ Ibid.

${ }^{6}$ Compiled by the authors on the basis of WCS, 2018

${ }^{7}$ Ibid.
} 
remains the subject of close attention of the leadership of modern China, which relates to the main source of electricity - coal (Figure 6).

Figure 6 The dynamics of total electricity consumption by China in million tons of the energy management system (EMS) and the share of sources of electricity for $1990-2015^{8}$
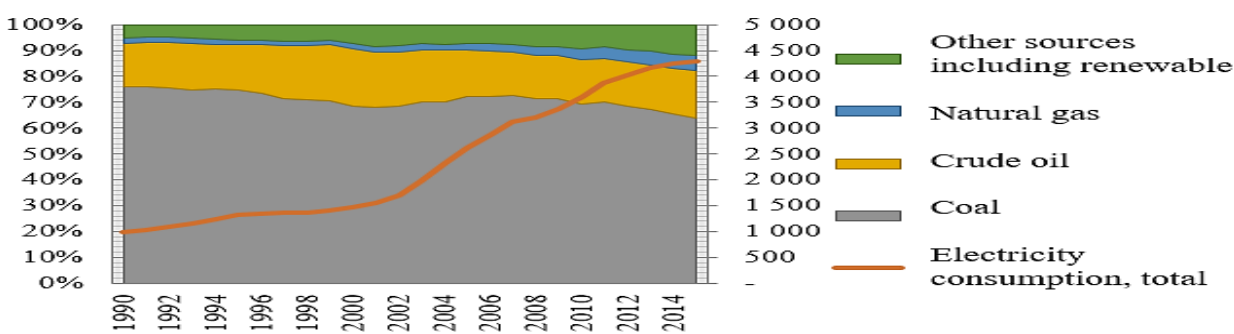

The main problem in meeting the domestic demand for electricity from coal is that, first, its deposits are dispersed throughout the country. At the same time, there are only $17 \%$ of coal reserves in the east and southeast of the country, which accounts for half of China's GDP. As a result, more than $60 \%$ of coal is transported by rail, which causes congestion, frequent accidents and, as a result, supply disruptions. Secondly, coal-fired power plants cause significant damage to the environment. In this regard, China pursues a policy of gradually reducing the share of coal among other sources of electricity, including by increasing the use of renewable energy sources (solar and wind power). Although at present, environmentally friendly new energy has a low proportion in the structure of energy consumption, it is recognized as a guideline for the future energy development of the country.

For these reasons, considering the long-term goals of the national electric power policy, participation in the project under consideration will allow China to continuously supply electricity from the Russian Far East to the border Chinese provinces, where there is a shortage in the event of a country refusal from coal-fired power plants. At the same time, it should be noted that to meet its needs, the power industry has enough investment and financial capacity to build large heat, power, hydro and nuclear power plants.

At the same time, research on the development of the Asian Energy Ring conducted by the Center for Energy Systems Skoltech showed that not only China, but also Japan would gain about $80 \%$ of the benefits from creating such an energy association due to the absence of the need to build new power plants, as well as using environmentally friendly and cheap energy sources. At the same time, the capacity utilization ratio of less than $50 \%$ in the Russian Far East (Table 1) will

${ }^{8}$ Compiled by the authors on the basis of CSY, 2016 
allow exporting unused energy. In turn, the refusal of Russia to participate in the project will reduce the efficiency of the operation of the electric power grid by $40 \%$.

Table 1. Installed capacity utilization factor (ICUF): production / installed capacity ${ }^{9}$

\begin{tabular}{|l|c|c|c|}
\hline \multicolumn{1}{|c|}{ Power pool } & $\begin{array}{c}\text { Installed capacity, } \\
\text { bln. kWh }\end{array}$ & $\begin{array}{c}\text { Power } \\
\text { generation, } \\
\text { bln. kWh }\end{array}$ & ICUF \\
\hline $\begin{array}{l}\text { Unified power system } \\
\text { of Russia (UPS) }\end{array}$ & 2070.37 & 1071.80 & $51.8 \%$ \\
\hline $\begin{array}{l}\text { Central unified power } \\
\text { system }\end{array}$ & 463.22 & 236.60 & $51.1 \%$ \\
\hline $\begin{array}{l}\text { Middle Volga unified } \\
\text { power system }\end{array}$ & 236.55 & 106.30 & $44.9 \%$ \\
\hline $\begin{array}{l}\text { Ural unified power } \\
\text { system }\end{array}$ & 447.91 & 258.40 & $57.7 \%$ \\
\hline $\begin{array}{l}\text { North-West unified } \\
\text { power system }\end{array}$ & 206.49 & 107.30 & $52.0 \%$ \\
\hline $\begin{array}{l}\text { South unified power } \\
\text { system }\end{array}$ & 180.47 & 96.20 & $53.3 \%$ \\
\hline $\begin{array}{l}\text { Siberia unified power } \\
\text { system }\end{array}$ & 455.26 & 206.90 & $45.4 \%$ \\
\hline $\begin{array}{l}\text { East unified power } \\
\text { system }\end{array}$ & 80.47 & 36.80 & $45.7 \%$ \\
\hline
\end{tabular}

\section{Results}

A retrospective analysis of Russian-Chinese cooperation in the power industry demonstrates the interest of the PRC, which, as an intensively developing economy, requires significant energy resources in the development of the Asian Super Grid project. In turn, the key task of Russia, not only in the case of a regional electric power cooperation project, but also in the development of bilateral relations (especially with the PRC), is to provide conditions for the socio-economic development of Russian resource and transit territories, as well as to realize economic and geopolitical interests of the country.

\section{Discussion}

In the long term, the "Chinese factor" is of the highest priority among the whole variety of opportunities for the development of economic ties in the Asian part, since strengthening the position of our country in this region largely depends on its relations with China. The growing geopolitical influence of the PRC makes the Chinese factor one of the key components of long-term political global and regional forecasting. In the current situation, it appears that the development of cooperation

\footnotetext{
${ }^{9}$ Compiled by the authors on the basis of Minenergo, 2018.
} 
with China in the Asian sector will not only help Russia solve the problems of ensuring the economic and technological development of its Asian part, primarily the Far East, but will also help strengthen its position in the European, "Atlantic" direction. Consequently, the project of an interstate energy association under consideration is increasingly becoming a factor of mutual growth and codevelopment for the near and more distant future. And this is at that time as with the West, Russia is developing an alternative (conflict) model of energy interaction.

At the same time, the interconnection of energy systems on a bilateral basis between China and Russia is already gradually proceeding, which creates the foundation for the implementation of the Asian Super Grid project in the future. Thus, Russia supplies excess electricity, which has a higher added value, from Amur region to the PRC for Northeast China, which is constantly experiencing its shortage. Cooperation in this area between the Russian Federation and the PRC began in 1988, when the management of the electric power industry of Heilongjiang Province concluded a protocol with the Office of the Electric Power Industry of Amur region on the supply of electricity to China based on barter trade.

But in the 2000s, barter transactions were terminated, electricity was supplied under contracts concluded in the summer of 2005 between the Russian joint-stock company "UPS of Russia" and the State Grid Corporation of China. In turn, prices were adjusted annually, and cases of failure to reach an agreement and termination of supply. In particular, from February 1, 2007, deliveries were suspended due to the introduction of new requirements by the Federal Tariff Service of Russia, according to which export prices could not be lower than domestic ones. Since this moment, price disagreements (the tariff for the PRC increased from 51 kopecks per $1 \mathrm{kWh}$ almost doubled) resulted in the suspension of electricity supply from the Russian Amur to China for 2 years (Kravchenko, 2008) As a result, idling discharges at the hydropower plants of Amur region (Zeya and Bureiskaya) led to the flooding of several settlements.

Electricity supplies were resumed after the parties managed to achieve a parity solution to the price issue when signing the most important document that determined the tendencies of bilateral economic cooperation for a decade. It was the Program of cooperation between the regions of the Far East and Eastern Siberia of the Russian Federation and the North-East of China for 2009-2018 (Cooperation program, 2009). In accordance with this program, the Russian side had to ensure the supply of electricity to China, and the Chinese side, together with partners, to carry out the construction of a direct current injection in China with a capacity of 750 $\mathrm{mWh}$ and a crossing over the Amur River, as well as the construction of new power plants and electricity in the Far East infrastructure. It is obvious that the implementation of such large-scale electricity supply projects will contribute to the development of the energy infrastructure of strategic regions of the country by attracting foreign investment. 
The cooperation program was signed by the President of the Russian Federation D.A. Medvedev and the PRC Chairman Hu Jintao on September 23, 2009 at the session of the UN General Assembly in New York. The document consists of the main part and the Annex. On signing it, there were 205 key cooperation projects in the Appendix - 94 projects related to Russian territory and 111 projects to Chinese. A detailed analysis of the list of key cooperation projects leads to the conclusion that the list of projects from the Chinese side has been worked out at a higher level.

Thus, the Russian side proposed mainly projects for the development of its natural resources (for example, the development of the Berezovsky iron ore deposit, etc.) and projects for non-primary production (for example, the establishment of a plant for the deep processing of soybean in Birobidzhan, etc.) were only partially introduced to consideration. While the Chinese side proposed projects related to mechanical engineering and the manufacturing industry (for example, the production of mining machines and copper sheets in Chifeng, etc.) (Cooperation program, 2009). In addition, the projects proposed by the Chinese side, as a rule, include such indicators as the exact location and annual capacity of the enterprise. Such an elaborated nature in its turn is not typical for Russian projects, which led to a highly controversial assessment of the document under study by domestic Sinologists. It seems that the first version of the Cooperation Program is clearly lobbying Chinese interests. Therefore, the Ministry of Regional Development of the Russian Federation has begun large-scale work to correct the apparent imbalance in the Cooperation Program, including such way as eliminating several projects.

In addition, when analyzing the Cooperation Program, our point deserves our attention according to which projects can be implemented by interested Russian and Chinese participants in foreign economic activity with a focus on market needs, provided they agree on technical, economic, financial and other parameters of cooperation (Section 6 "Key Projects of Regional cooperation"). Proceeding from this, it follows that the implementation of projects is possible only considering the interests of both economic parties, i.e. in the presence of a relationship of interests of companies, representatives of local and central authorities of the Russian Federation and the PRC. It seems that this paragraph excludes the possibility of negative consequences in the implementation of a project that does not meet national interests.

Thus, the implementation of the interstate project meets the development trends of the Russian-Chinese electric power cooperation, since the import of electricity from Russia will be associated with investments. Chinese investments are necessary for the domestic electric power sector due to insufficient operating capacities for the planned scale of exports to China in the long term. Thus, the leadership of China's northeastern provinces to pool local resources for the development of the electric power market of Russia established the Union for the Development of Electricity Cooperation with Russia in 2010 in Harbin. It consists of 43 members, including 
enterprises to produce electric power equipment, research and design organizations, financial institutions, construction and trading companies.

The next stage of development of the Russian-Chinese cooperation in the electric power industry is associated with the signing the first long-term contract for the supply of electricity with a maximum supply of 100 billion kWh between PJSC "Inter RAO" and the State Grid Corporation of China in 2012 for 25 years. Even though it is not possible to fully assess the long-term effect of electricity exports for the energy infrastructure of the Far Eastern region, the signing of such an agreement indicates the intention of both countries to work towards strengthening economic ties and considering the possibility of strengthening the integration processes.

In turn, the assessment of Russia's economic benefits from sales under the terms of this agreement reflected in the doctrine shows that in 2012 Russia sold electricity to China more expensive than the domestic market, while China bought cheaper than it produced itself (Poliakova, 2016). We believe that the export of electricity at this price, given the isolation of the energy system of the Far East and the presence of excess generating capacity, which in idle discharges flood adjacent territories, is beneficial to the Far Eastern generating companies and network companies receiving additional income.

Assessing the profitability of the supply of the electric power industry, a widespread mistake also deserves special attention when the value of the export price, which by its nature is related to the wholesale market, is compared with the retail price. The bottom line is that retail prices for electricity consumers, both in Russia and in any other country, are significantly higher than wholesale prices. For example, Chinese enterprises such as automobile maintenance centers paid electricity at 936 yuan for 1 MWh (US\$ 146 for $1 \mathrm{MWh}$ ) in 2011, which is comparable to the tariff for similar customers in the Far Eastern Federal District, where end-user subsidies are applied when paying electricity tariffs. In turn, the retail price is determined by the additional, very substantial costs of delivering electricity to the final consumer (for example, the costs of transportation and distribution of electricity, etc.). In addition, the final price of electricity to the final consumer necessarily includes the necessary rate of profit of the entire chain of intermediaries involved in the process of supplying electricity to the final consumer and taxes.

The visit of V.V. Putin to China in May 2014 served the catalyst for the further development of the Russian-Chinese energy partnership, which, as has already been established, is of a strategic nature for the two countries because of both political and economic factors. In the framework of this visit, V.V. Putin and Xi Jinping signed a package of documents to expand the development of Chinese investors in various sectors of the Russian energy industry. In particular, the heads of the states signed an agreement that would strengthen cooperation in the area under study, including through the construction of new power generation facilities in Russia for the subsequent increase in electricity exports to China. 
It should also be noted that recently Russian-Chinese cooperation in the field of bioenergy and renewable energy has received some development. This is conditioned by the energy strategy of the PRC, which according to Premier of the PRC State Council Li Keqiang, is aimed at accelerating the development of economically clean energy sources to improve the quality of the country's environment (Shapiro-Bengtsen, 2017). For example, in 2011, the Russian Energy Agency, PJSC "Inter RAO UPS”, the National Bioenergy Company of China (NBE) signed a framework agreement on the establishment of the Russian Federation by the end of 2011 in Russia as part of the state visit of China President of the RussianChinese joint venture "Green Energy Corporation".

According to the agreement on cooperation, the activity of the company covers the following areas: 1) construction of power plants operating on various types of biomass for the production of heat and electrical energy, biogas; 2) updating of already existing coal and mazut power plants with low rates in the production of electricity; 3) creating factories for the production of pellets from peat, wood waste and other biomass; 4) attracting investments for the implementation of priority projects.

\section{References:}

Austin, A. 2005. Energy and Power in China: Domestic Regulation and Foreign Policy. Preface by Gong Li and Mark Spelman, available online: https://www.files.ethz.ch/isn/23685/Energy_Power_China.pdf

Cooperation program. 2009. Program of cooperation between the regions of the Far East and Eastern Siberia of Russia and North-East China for 2009-2018. Officially approved by the President of the Russian Federation D.A. Medvedev and the Chairman of the People's Republic of China, Hu Jintao, on September 23, 2009, during a meeting in New York.

CSY. 2016. China Statistical Yearbook. Available online: http://www.stats.gov.cn/tjsj/ndsj/2016/indexeh.htm

Farmer, J.D., Trancik, J. 2012. Dynamics of Technological Development in the Energy Sector. Santa Fe Institute.

Kapustin, A.Ya. 2012. Russia and APEC: an economic strategy of interaction. APEC Summit: Legal Mechanisms for Regional Integration. Moscow, Statute, 125.

Kravchenko, M. 2008. Business Guide - Electroenergy 4.0, 232, 2, available online: https://www.kommersant.ru/doc/1116583

Minenergo. 2018. Ministry of Energy of the Russian Federation's analytics. Available online: https://minenergo.gov.ru/

Movellan, J. 2016. The Asia Super Grid - Four Countries Join Together to Maximize Renewable Energy. Official website of Renewable Energy Network: http://www.renewableenergyworld.com/articles/2016/10/the-asia-super-gridcountries-join-together-to-maximize-renewable-energy.html

Poliakova, M.R. 2016. Facing East: the potential for exporting electricity from Russia to China. Security issues, 1, 27-38. DOI: 10.7256/2409-7543.2016.1.18053, available online: http://e-notabene.ru/nb/article_18053.html 
Putin, V.V. 2016. Speech at the Eastern Economic Forum in Vladivostok. Broadcast 360, available online: http://e-news.su/mnenie-i-analitika/131108-vef-2016-vystuplenievladimira-putina-na-vostochnom-ekonomicheskom-forume-vo-vladivostoketranslyaciya-360.html.

Rensselaer, W.L. 2013. The Russian Far East: Opportunities and Challenges. Foreign Policy Research Institute, available online: https://www.fpri.org/docs/Lee_April_2013.pdf.

Semashko, N. 2016. Energy Grid of the East. Business Guide «Electricity 4.0», 33, 3, available online: https://www.kommersant.ru/doc/3113919.

Shapiro-Bengtsen, S. 2017. Wasting less renewable energy could boost China's air quality. Avaiable online: https://www.chinadialogue.net/blog/9695-Wasting-less-renewableenergy-could-boost-China-s-air-quality/en.

Shuta, M., Bavuudorj, O., Zafar S. 2014. GOBITEC and Asian Super Grid for renewable energies in Northeast Asia. Published with the financial support from the Energy Charter Secretariat and the Energy Economics Institute of the Republic of Korea, available online:

https://energycharter.org/fileadmin/DocumentsMedia/Thematic/Gobitec_and_the_Asi an_Supergrid_2014_en.pdf.

UNESCAP. 2018. KEPCO's Future Plans of Northeast Asia Supergrid. Official website of UN Economic and Social Commission for Asia and the Pacific, available online: http://www.unescap.org/sites/default/files/ Session\%203.2\%20Junghwan\%20Yo on_ROK.pdf.

WCS. 2018. Global Energy Statistical Yearbook. Available online: https://yearbook.enerdata.net/total-energy/world-consumption-statistics.html. 